\title{
Traces of the Neuter Gender in Modern Scottish Gaelic
}

\section{Author(s): Professor Mackinnon}

Source: The Celtic Review, Vol. 6, No. 24 (Apr., 1910), pp. 296-304

Stable URL: http://www.jstor.org/stable/30070227

Accessed: 20-06-2016 15:12 UTC

Your use of the JSTOR archive indicates your acceptance of the Terms \& Conditions of Use, available at

http://about.jstor.org/terms

JSTOR is a not-for-profit service that helps scholars, researchers, and students discover, use, and build upon a wide range of content in a trusted digital archive. We use information technology and tools to increase productivity and facilitate new forms of scholarship. For more information about JSTOR, please contact support@jstor.org. 


\section{TRACES OF THE NEUTER GENDER IN MODERN SCOTTISH GAELIC}

\section{Professor Mackinnon}

ONe of the many truths which the great Celtic Grammarian, Zeuss, was able to establish was the existence of the Neuter Gender in Celtic as in the other Aryan Languages. In the old MSS. from which the Gaelic portion of the Grammatica Celtica was mainly constructed, - the glossed copy of Priscian's Grammar in St. Gall (Sg.); the glossed copy of the Epistles of St. Paul in the University of Würzburg (Wb.); the glossed copy of a commentary on the Psalms formerly in the monastery of Bobbio, founded by Columbanus a monk of Bangor, but now in Milan (Ml.); and the Book of Armagh (B.A.) in Dublin-distinctive Neuter forms abound for the Article, Noun, Adjective, and Pronoun, all of which are duly set forth for the first time in that monumental work. Succeeding scholars have corrected and extended in minor details the examples adduced by the illustrious master, but the existence of the Neuter in Celtic, and especially in the Gaelic dialects, is now an axiom with Gaelic grammarians. These Neuter forms have now all but disappeared from the modern Gaelic tongues, but, as is always the case, they have left interesting traces behind them in the dialects of to-day which we are so far able to explain by the light which the old writings of the language throw on the Neuter Gender.

In Celtic, as in the Classical tongues, Grammatical Gender was originally no doubt based upon sex. But very early certain Noun-stems came to be regarded, grammatically, as Masculine or Feminine, although, in meaning, the nouns themselves could not be spoken of as Male or Female. Such was the case in all the old Aryan tongues, and such is the case in many modern languages, as German, e.g. English alone has been able in a comprehensive manner to equate Grammatical Gender with Nature and Sex, where 
the names of Males are all grammatically Masculine, the names of Females Feminine, and all others Neuter-that is neither (Male nor Female) Masculine nor Feminine. The fact that English has no flexion of Article or Adjective has no doubt greatly simplified the convenient and practical distribution of Grammatical Gender in that tongue. The Pronoun as the substitute or representative of the Noun has alone to be considered.

In passing from a language with three Genders to one which has only two, considerable inconveniences and frequent confusion necessarily arise. The Gael has at first a difficulty in correctly apportioning many of his ' he's' and 'she's' among the English 'it's,' while the Saxon is equally at a loss in properly distributing his 'it's ' among the Gaelic and French 'he's' and 'she's.' Nor is his task much lightened in turning to German where he finds the lists of Masculine, Feminine, and Neuter Nouns so very different from his own.

In the development of Grammatical Gender it appears that the Neuter came later than the Masculine and Feminine. The Sanskrit grammarians called the new class of Nouns kliva, 'eunuch,' but the Latins, from whom the moderns have so largely borrowed the technical terms of grammar, were satisfied with the prosaic neutrum, ' neither.' English which had its native word ' neither' formed like the Latin could very easily have specialised its meaning in grammar to neuter, but it evidently became the fashion early in the history of that language to borrow from the foreigner, even when there was no need to do so. According to Cormac, the old lexicographer, Gaelic had two terms meaning neuter-deme .i. cech neutur lasin laitneoir is deme lasin filid n-gaedalach, ' everything neuter with the Latinist is deme with the Gaelic poet'; and traaeth .i. cach nechtraige 7 cach neotur, 'traaeth i.e. everything neutral and neuter.' (Three Irish Glossaries, deme, traaeth.) But the old Gaelic grammarians, like the English, preferred to borrow the Latin term than to use the native one. It may be added that the language also 
possessed a native word for the useful word 'neither,' formed exactly like neutrum and 'neither,' but which we have allowed to fall into disuse. In old Gaelic nechtar meant ' one of two.' Later the Adjective nechtarde was formed ; and by prefixing neb-, nemh- (now neo-) to this word, we formed neo-neachtardha, 'neither.' Thus (MS. iv. Adv. Lib.) neutrum .i. nemhnechtarda of which the writer gives four definitions, the shortest being : neutrum est res non sana non egrota .i. is ed is nemhnechtarda ann red gan beth slan no eslan, ' what is neither well nor ill.'

It is a striking coincidence that in the Romance Languages, the descendants of Latin, the Neuter Gender has disappeared as in the Celtic dialects; that in both groups interesting survivals of the old Neuter remain ; and further that while many Nouns formerly Neuter have become Feminine, much the greater number are now Masculine.

Scottish Gaelic, unlike English, still declines the Article and Adjective. In the modern language we may say generally, avoiding details, that in the case of Feminine Nouns, the Article causes the aspiration of the Noun, and the Noun causes the aspiration of the Adjective, in the Nominative Singular ; while with Masculine Nouns aspiration does not take place : $a$ ' bhean mhor, 'the big woman,' but am fear mor, 'the big man.' The former is of course represented by $i$, the Fem. Pers. Pronoun, the latter by è the Masc. Pers. Pronoun. We have thus two tests to settle the Gender of a Noun in Gaelic, the Article and Adjective test, and the Pronoun test. We shall find later that there is a group of Nouns which are Masculine or Feminine according as one gauges them by the one test or the other.

Let us now consider cases of the survival of the Neuter in Modern Gaelic, and thereafter treat of the confusion which the disappearance of the Neuter has wrought in the Gender of Gaelic grammar.

I. Take the case of $e d$, now eadh.

The old grammarians wrote the third person Sing. of the Pers. Pron. thus : 
Masc. é ; Fem. sí; Neut. ed;

with their emphatic forms :

Masc. é som; Fem. sisi ; Neut. ed ón.

When Neuter Nouns came to be classed as Masc. or Fem. the main function of the Neuter Pronoun ed became merged in $e$ and sí. Still the word was not entirely dropped. We write the simple form eadh and the emphatic form eadhon; and we use the former idiomatically, with fringes of its neuter vesture still clinging to it. Thus when one is reciting verse or telling a story, and when you feel that he merits approval you encourage him to proceed by saying 's eadh, 'it is,' 'yes' ('s è would be quite out of idiom). So also in the well-known passage (Matt. v. 37): 'Ach gu ma $h$-è is còmhradh dhuibh 'S eadh,'s eadh; ni h-eadh, ni h-eadh : oir ge b'e ni a bhios os cionn so, is ann o'n olc a tha e'. Here Scottish Gaelic usage would demand cha'n eadh instead of $n i h$-eadh, which is the common Irish form, otherwise the idiom is correct. ' $S \grave{e}$ and $c h a ' n \grave{e}$ would be idiomatically wrong. If you wish to ask such a question as ' Is he a native of Mull ?' e.g. you can do so in one of three forms, all idiomatically correct: (1) An ann de mhuinntir Mhuile a tha e ? to which the answer would be, 'S ann or cha'n ann; (2) An $\dot{e}$ Muileach a tha ann ? the answer now being, 'S è or cha'n è ; (3) Am Muileach e ? the proper reply to which is, ' $\mathrm{S}$ eadh or cha'n eadh. So where the chief captain asked St. Paul (Acts xxii. 27) if he was a Roman, the question is put in the form, An Romanach thu? and the answer is given idiomatically correct, Is eadh, not is è. Similarly if I come upon an animal, a dog or a horse, showing temper, I turn and say $A n$ eadh? or in English, 'Would you ?' From these examples of the idiomatic use of eadh in Scottish Gaelic, as also in Irish, it will be seen that eadh distinguishes from $\grave{e}$ in that the latter responds to a person or concrete individual thing, while the former is concerned with an idea, a concept, a predication, which in its nature is essentially Neuter-in fact eadh is in living use as a Neuter in Gaelic right down from Neuter days. 
It may be added that ed on, now eadhon, came in the old language to be chiefly used in the sense of viz., ' namely,' ' to wit,' etc., just as the word is mainly used now. Other forms into which $e d$, eadh, entered, such as ma's eadh (ma seadh), gidheadh, etc., are in use in the modern as in the old language, but from the nature of the case their idiomatic use is not connected with Gender.

The case of cid, now ciod:

In the old language the Interrogative Pronouns, ce, cia, were not distinguished in respect of Gender. But very early these were combined with the Personal Pron., and distinction of Gender emerged : ce hé, 'quis' ? ce si (cisi) 'quae' ? ced, cid ( $c e e d)$, 'quid'? These distinctions have so far remained. Cisi has disappeared, and we now use co for quis? and quae? indifferently. We have cia which is used in dialect more or less frequently for co; but ciod still represents the old cid, 'quid'? 'what'? Ciod has in construction taken the Pers. Pron. $\dot{e}$ after it. The stress is upon the $\grave{e}$, and accordingly ciod $\grave{e}$ has in common speech become $g u$-dé? and even dé? in the sense of 'what?'

As between co and ciod, the one referring to persons the other to things, no mistake is ever made: Co tha thu faicinn? 'Whom are you seeing'? Ciod(gu-dé, dé) tha thu cluinntinn? 'What are you hearing?' But some confusion emerges when the personal pronoun $\grave{e}$ or $\grave{i}$, referring to a specific Masc. or Fem. Noun joins to ciod. We have seen that in popular speech $\grave{e}$, but not $\grave{i}$, has attached to ciod in the form gu-dé, dé for ciod è, but not gu-dì, dì for ciod $i$. This is no doubt due to the fact that the Masc. and not the Fem. has replaced the disused Neuter. ed. We say dé do bharail? for the literary ciod $i$ do bharail? "What is your opinion?' as well as dé do bheachd for ciod é do bheachd? 'What is your conviction?'

It looks as if it were here we should find the explanation of such phrases as ciod è urnuigh instead of the form one should look for ciod ì urnuigh, seeing that urnuigh is a Fem. noun. The anomaly did not escape the notice of the 
capable Gaelic Grammarian, Dr. Alexander Stewart, whose shrewd observations on this point, as also upon the proper meaning of Grammatical Gender (v. Gram., ed. 1812, pp. 42, 160), prove him to have been an able exponent of philosophical Grammar. Had Dr. Stewart known the old forms of Gaelic and especially the disused Neuter forms, he would have found in them a simpler and more satisfactory explanation of these and other abstruse points in Gaelic Grammar than among the subtleties of scholastic philosophy.

II. The confusion which the disappearance of the Neuter has caused in the Gender of Nouns in modern Gaelic.

In the fourth volume of the Todd Lecture Series (Dublin, 1892), Father Hogan has printed an exhaustive list of nouns which were Neuter in old Gaelic. An examination of this list shows that, as already stated, much the greater number of these have become Masculine in the modern language, although the number that joined the Feminine is considerable. A few have left behind them in names and phrases traces of their earlier grammatical association. We may take a few examples : Tir, 'land,' as distinct from muir, 'sea,' was of old a Neuter noun, although the word is now and has been for many generations, all over Gaelicspeaking land, Feminine. It regularly takes the adjective attached to it in the aspirated form, tir mhor fharsuing, 'a great spacious land,' and the Article when prefixed to it declines in the Feminine, feadh na tire, 'throughout the land.' But an Islander still says tir-mor (not tir-mhor) when he speaks of the mainland of Scotland, and the Mainlander says tir-mor when he speaks of the Continent of Europe. In the same way Islander and Mainlander alike say teachd-an-tir (not teachd-na-tire), 'yield of the land,' 'sustenance,' 'food.' The true explanation of these and similar phrases is that they were formulated and, so to speak, petrified when tir was still a Neuter noun, and subjected the Article and Adjective attached to it to the forms of the Neuter. 
Muir, ' sea,' like tir, ' land,' was of old a Neuter noun, and is now Feminine. In some localities muir still retains some reminiscences of its old gender; am muir is heard in some districts for a'mhuir and muir mar instead of the common muir mhor in the Nominative; but on the other hand taobh na mara, 'seaside,' seems to be the only form in use for the Genitive. In place-names, however, Ceann$a$ '-mhara (Kenmare), ' end of the sea,' is met with, a case of the Neuter form surviving in the Genitive.

Traigh, ' beach,' 'ebb,' is another Neuter noun which has become Feminine. In the old language there were two words denoting ' beach,' 'strand,'-tracht and traig. The latter became Fem. very early; it is marked so by Professor Windisch. The noun is now commonly declined in the dental declension: Nom., an tràigh, Gen. na tràghadh. In place-names the old Neuter form is clearly in evidence ; Bail'-an-traid, Dail-an-tràid, Ballantrae. A beautiful beach of pale yellow sand is still in Colonsay An Traigh bàn, while all the others are traigh bhàn (or gheal). (Cf. the last number of this Review, p. 245 'o Thràigh Bàin Mhùideart.)

Inbhear or inbhir, ' river mouth,' although marked Masculine in Windisch's vocabulary, was a Neuter noun in old Gaelic. The word retains its old form and declension in the North Highlands, as e.g. Loch-an-inbhir, 'Lochinver,' in the west of Sutherland, but in the southern Isles it has become Feminine, and takes the guttural declension in the Genitive,-Tigh na $h$-in(bh)earach 'Inverhouse' (Jura); Bodha na h-in(bh)earach, 'Inver reef' (Colonsay).

In addition to this group of Nouns, which might be enlarged, whose history preserves traces of their fluctuations in Gender, there is a number of quite common words of varying gender in Gaelic dialect, a circumstance which may be confidently attributed, directly or indirectly, to the disappearance of the Neuter from the language. Such a word is muileann, ' mill,' a loan from the Latin molendinum. In most districts this word is Masculine, but it is Feminine in the island of Lewis and elsewhere. Ugh, 'egg,' the 
cognate of (or a loan from) the Latin ovum, though Masculine over the greater part of the Scottish Gaelic area, is Feminine in several localities. So are teine, 'fire,' sgeul, ' tale,' ubhall, 'apple,' eallach, 'burden,' with many others, all originally Neuter, but now Masculine in one district, Feminine in another.

In Gaelic Grammar we reckon Nouns as Masc. or Fem. according as they take the Article and Adjective conjoined with them in the Masc. or Fem. form. But when we substitute a Pronoun for these Nouns, the Fem. Pron. sometimes represents a Noun which is by the Article and Adjective test, grammatically, Masculine. Some of these cases can be explained in a more or less satisfactory way. Bàta, 'boat,' and soitheach, 'vessel,' are Masc. nouns, i.e., they take the Article and Adjective in the Masc. form; but they are invariably represented by the Fem. Pron. $i$, 'she,' never by $\grave{e}$, 'he.' In this case the explanation may be, probably is, that in Gaelic as in English every class of boat is treated as a 'she,' a circumstance natural enough in Gaelic from the fact that long, 'ship,' is and always has been Fem. In other cases where the subject is not a word but a clause or sentence the representing Pronoun is the Masc. which takes the place of the old Neuter. Thus $d h$ 'ith na bà caola suas na bà reamhra, agus cha'n aithnichteadh orra è, 'The lean cattle ate up the fat cattle, and it could not be known of them' (Gen. xli. 20). In the case of living beings Gaelic usage demands the pronoun that represents the Sex of the Subject rather than the Gender of the Noun. In this connection the observations of Dr. Stewart are so clear and to the point that they are well worth quoting (Gr., p. 158).

'The Personal and Possessive Pronouns follow the Number of their Antecedents, i.e., of the Nouns which they represent. Those of the third Person Sing. follow also the Gender of their Antecedent; as, Sheas a' bhean aig a chosaibh, agus thoisich i air am fliuchadh le a deuraibh, agus thiormaich i iad le gruaig a cinn, "The woman stood at his feet, and she began to wet them with her tears, and she wiped 
them with the hair of her head' (St. Luke vii. 38). They follow, however, not the Gender of the Antecedent, but the Sex of the creature signified by the Antecedent, in those words in which Sex and Gender disagree; as, an gobhlangaoithe mar an ceudn' do sholair nead dhi fein, 'The swallow, too, hath provided a nest for herself' (Ps. lxxxiv. 3). Gobhlan-gaoithe, 'swallow,' is a Masc. Noun, as appears by the Masc. Article ; but as it is the dam that is spoken of, the reference is made by the Pers. Pron. to the Fem. Gender. Ta gliocas air a fireanachadh le a cloinn, "Wisdom is justified by her children' (St. Matt. xi. 19). Gliocas is a Masc. Noun, but as Wisdom is here personified as a female, the regimen of the Poss. Pron. is adapted to that idea.'

There seems little doubt but that the sagacious author has hit upon the true explanation of the Gaelic usage in this matter, and that thus we must also explain the invariable use of the Fem. Pronoun to represent such words as mart, ' a cow,' capull, 'a mare,' and boirionnach, 'a female,' 'a woman,' with one or two others which are, grammatically, Masc. Nouns.

\section{THE SCOTTISH RACE AND KINGDOM}

\section{James Ferguson}

I

Two great developments in the history of Scotland are shrouded in mist, and present fascinating subjects for investigation and speculation. One is the process by which, in the long period between King Malcolm Canmore and the union of the Crowns, the Teutonic overshadowed the original Celtic element in the population of the Lowlands from the Forth to the Findhorn, and the Gaelic tongue was superseded by the English speech. The other is the earlier change by which the proper Scots, whose original territory was limited to the county of Argyll, became supreme over 